\title{
SUMARIO ANALÍTICO
}

\section{¿EN QUÉ DEMOCRACIA VIVI(RE)MOS? REFLEXIONES DESDE Y PARA AMÉRICA LATINA CÉsar Cansino}

Resumen: El artículo analiza el tipo de democracia que se ha implementado en los países de América Latina tras los procesos de cambio político experimentados en la región en las últimas décadas. El autor defiende la necesidad de buscar un nuevo concepto de democracia que ponga el énfasis en la sociedad civil. A diferencia de los enfoques teóricos europeos y anglosajones, la democracia no entraña sólo un sistema de gobierno sino un sistema de interacción social.

Palabras claves: democracia representativa, sociedad civil, espacio público, secularización, conflicto América Latina.

\section{LOS NOVENTA EN AMÉRICA LATINA: ¿LA DÉCADA DE LAS OPORTUNIDADES O DE LAS QUIMERAS? SAlvador Martí I PUig}

Resumen: El presente artículo pretende esbozar una mirada crítica de lo acontecido en América Latina, a nivel político, durante los años noventa con el afán de responder porqué a finales de la década se desvaneció el entusiasmo y las espectativas con que ésta empezó. Para ello el primer epígrafe da cuenta de la reaparición del fenómeno populista y la constante inestabilidad que caracterizó a los países de la región. Posteriormente se pasa a analizar el carácter de los regímenes democráticos resultantes de los procesos de transición desde sistemas autocráticos y el impacto social de las políticas económicas de cuño liberal que aplicaron todas y cada una de las administraciones latinoamericanas. Después se debate sobre el fenómeno recurrente de la violencia en la arena política y social, y sus múltiples formas (desde los conflictos armados hasta la delincuencia común), y finalmente, se concluye con el intento de ubicar cuál es la posición y el espacio de los ciudadanos en estos regímenes que dicen basar su legitimidad en el voto popular y el consenso.

Palabras clave: democracia, procesos de cambio político, neopopulismo, crisis política e inestabilidad institucional, América Latina, neoliberalismo.

\section{¿MÁS ALLÁ DEL “CONSENSO DE WASHINGTON”? UN ENFOQUE DESDE LA POLÍTICA DE ALGUNAS PROPUESTAS DEL BANCO MUNDIAL}

\section{Carlos M. Vilas}

Resumen: Durante la última década las recomendaciones de política del Banco Mundial han puesto énfasis en la reforma institucional y en un papel más activo del Estado en la promoción de las transformaciones económicas orientadas hacia el mercado. La atención prestada a estos temas contrasta con la trayectoria previa del organismo, preocupada sobre todo por la gestión de los grandes agregados macroeconómicos. La nueva temática es presentada como respondiendo a la conveniencia de ir más allá del "Consenso de Washington" que influyó decisivamente en las reformas estructurales de la década de 1980 e inicios de la siguiente. Este artículo discute los alcances y limitaciones de la nueva propuesta desde una perspectiva política, poniendo el acento en las configuraciones de poder que enmarcan las recomendaciones del organismo. Se reconocen en éstas dos vertientes: una de carácter doctrinario, preocupada ante todo por completar el programa de reformas impulsado por el "Consenso", y otra, pragmática, que plantea la reformulación de algunas de sus premisas en aras de un efecto más equilibrado en términos económicos y sociales. Aunque difieren en el margen de acción que reconocen para el Estado, ambas variantes comparten un enfoque que da prioridad a los instrumentos de gestión respecto de los grandes objetivos del desarrollo, reduce la política a administración y soslaya la historicidad del Estado y de la construcción institucional.

Palabras Clave: Recornendaciones del Banco Mundial, reforma institucional, papel del Estado.

\section{LOS EJES DE LA TERCERA VÍA EN AMÉRICA LATINA Roberto Patricio Korzeniewicz y William C. SMith}

Resumen: Este artículo analiza los desafíos actuales para el desarrollo de una Tercera Vía de corte social democrático en América Latina. Una vez revisadas las diferentes perspectivas y criticas en torno a dicho proyecto, este trabajo especula sobre su proceso de implementación y las posibilidades que el mismo brinda para la formación tanto de un nuevo Régimen Internacional de Política (RIP) como de un nuevo Sistema Global de Bienestar (SGB). El argumento principal es que a pesar del impacto significativo que los aggiornados proyectos social democráticos tendrían sobre la formación de un RIP en América Latina, el protagonismo y relevancia social y político de la Tercera Vía serían menores sin la simultánea articulación de un SGB, algo que los autores estiman como poco probable. El artículo concluye con una discusión sobre los posibles escenarios alternativos para la Tercera Vía y los procesos de transformación social y política en América Latina.

Palabras clave: Tercera Vía, Democracia, Desigualdad, Estado. 


\section{BOLIVIA, LA OTRA QUE QUIERO Y QUE EMPEZABA A DESCONOCER. REFLEXIONES EN TORNO AL INFORME DE DESARROLLO HUMANO EN BOLIVIA 2000 LuIS VERDESOTO CUSTODE}

Resumen: El artículo -que comenta el Informe Desarrollo Humano de Bolivia 2000- se pregunta ¿qué significa globalizarse para un país? ¿Es posible medirla desde las dimensiones subjetivas de la interacción social? ¿Cuáles son los límites de la modificación de la "personalidad social" de las naciones? Para proyectarse en el mundo globalizado es necesario interactuar desde la definición de los intereses "propios". Hay que definir los cambios en los paradigmas de la subjetividad para asumir la comparación y examinar las aptitudes para conservar y modificar a la nación. En suma, ¿Estamos construyendo formas específicas de ser en la globalización? La forma de entendernos en los "poderes" de la globalización es disponer de un arsenal mínimo de "saberes". Es una medición de la autonomía para relacionarse. Permite "negociar” la inserción en la globalización, que plantea las formas de una construcción conjunta y conflictiva de los sentidos de la historicidad (compromisos). Acerca de las tareas pendientes, en el ámbito político, el artículo sostiene que deben fortalecerse las instituciones: cuando la sociedad asedia con su dinámica contradictoria, las instituciones no pueden construir su lógica valórica. En el ámbito económico, debe re-enrumbarse el sentido de la competitividad: ¿Se puede conducir la eficiencia hacia la solidaridad? En el ámbito social, debe superarse la extrema pobreza: existe una enorme incapacidad para producir un pacto nacional contra la pobreza ya que los pactos políticos no tienen pactos sociales de sustento.

La educación aparece como la posibilidad de (re) conocer a la inserción internacional como una oportunidad. Es una apuesta por la ciudadanización, ejercicio de la capacidad de elección de los usuarios de la democracia. La utilización de las instituciones de la democracia está sustentada en la implantación ininterrumpida de la ciudadanía. Para que los valores sean parte del desarrollo deben ser plurales y reconocerse en el sentido histórico de cada sociedad. El autor propone que se debe descubrir el tipo de asociación entre lo racional y lo afectivo tanto como conseguir una definición de individuación así como también puntualiza respecto al papel que las elites dirigentes desarrollan en esos procesos.

Palabras clave: Informe de Desarrollo Humano, Sociedad Civil, efectos de la globalización, Bolivia.

\section{¿JUICIO POLÍTICO O GOLPE LEGISLATIVO? SOBRE LAS CRISIS CONSTITUCIONALES EN LOS AÑOS NOVENTA}

\section{ANÍBAl PÉrez LiÑán}

Resumen: Este artículo analiza las crisis políticas que terminaron con los gobiernos de Fernando Collor en Brasil (1992), Carlos Andrés Pérez en Venezuela (1993), Abdalá Bucaram en Ecuador (1997) y Raúl Cubas Grau en Paraguay (1999) desde una perspectiva comparada. Los casos son utilizados como ejemplos similares, y las experiencias de Carlos Menem, Alberto Fujimori y Ernesto Samper son invocadas como fuentes de contraste. La evidencia sugiere que todo presidente corre el riesgo de ser depuesto por el Congreso cuando tres factores se conjugan en su contra: a) el escándalo político erosiona su autoridad; b) la opinión pública se moviliza en su contra -usualmente como resultado de una economía en crisis- y c) el Ejecutivo carece de recursos para controlar al Congreso. Tras estas condiciones normalmente se esconde un marcado aislamiento político del presidente y una fuerte oposición de las elites a su estilo de gobierno.

Palabras clave: Juicio político, crisis institucional, Poder Ejecutivo, Congreso, escándalo político. 


\section{ANALITICAL SUMMARY}

\section{IN WHAT DEMOCRACY ARE (WILL) WE (BE) LIVING IN? REFLECTIONS FROM AND FOR CÉsAR CANSINo}

Abstract: This paper analyzes the type of democracy that has been implemented in Latin American countries after the processes of political change that have taken place in the region over the last decades. According to the author a new concept of democracy, with an special focus on civil society, has to be searched. In contrast to European and Anglosaxon theoretical approaches, democracy is not only about a system of government, but about a system of social interaction.

Key words: representative democracy, civil society, public sphere, secularization, conflict Latin America.

\section{THE 1990s IN LATIN AMERICA: A DECADE OF OPPORTUNITIES OR CHIMERAS? Salvador Martí i Puig}

Abstract: This article critically overviews the main political events that have been taking place throughout the 90s with the aim to respond why is it that the enthusiasm and expectations with which the decade started vanished at the end. With that purpose, the first part of this work gives account of the re-emergence of populism and the unending instability that characterized the countries of the region. Subsequently, the character of the democratic regimes resulting from the transition processes and the social impact of the economic policies with neoliberal leanings applied by every single Latin American government, will be analyzed. Subsequent to the debate over the recurrent phenomenon of violence in the social and political arenas, in its multiple forms (from the armed conflicts to the common delinquency), the article finally concludes with an intent to locate the spaces and positions of the citizens of these regimes that say to ground their legitimacy on popular vote and consensus.

Key words: Democracy, Institutional Changes, Neopopulism, Political Crisis, Political Inestability, Latin America, Neoliberalism.

\section{BEYOND THE WASHINTON CONSENSUS? A POLITICAL SCIENCE APPROACH TO SOME WORLD BANK PROPOSALS Carlos M. Vilas}

Abstract: Over the last decade, World Bank's political prescriptions have stressed on institutional reforms and on a more active role of the State in promoting market-oriented refoms. However, this organism has traditionally focused on macroeconomic aggregates. This new approach is rooted in 'Washington Consensus' and its a decisive impact on the structural reforms that took place over the nineties. This paper discusses, from a political perpective, achievements and limitations of this new approach. It emphasizes on the power configurations that frame this organism' prescriptions. These prescriptions have a double character. On one side, there is a doctrinary character: the fulfillment of the package of reforms. On the other side, there is a pragmatic character: the reformulation of some of its postulates in order to achieve, in economic and social terms, more balanced effects. Despite differences in the attributed State's scope of action, both perspectives emphasize on management tools to achieve the main goals for development, both of them reduce politics to administration, and both of them ignore historicity of States and of institutional frameworks.

Key words: World Bank's prescriptions, institutional reform, State's role.

\section{THE TWO AXIS OF THE THIRD WAY IN LATIN AMERICA Roberto Patricio Korzeniewicz William C. Smith}

Abstract: This article analyzes current efforts to develop a progressive "Third Way" to social and political reform in Latin America. After briefly reviewing the perspectives of advocates and critics of such a poitical strategy, the article distinguishes the likely future of such a strategy in shaping the emergence of (1) a new "International Policy Regime" (IPR); and (2) a "Global Welfare System" (GWS). The article argues that although "Third Way" projects are likely to have a significant impact in shaping a new IPR in Latin America, they are less likely to result in the development of a GWS. Without the latter, the greatest political impact of a "Third Way" is likely to be restricted primarily to high income countries. We conclude by discussing alternative scenarios for "Third Way" reform and the implications of these projects for contemporary patterns of social and political change in Latin America.

Key words: Third Way, Democracy, Inequality, State. 


\section{THE OTHER I WANT AND DO NOT KNOW ABOUT \\ LUIS VERDESOTO}

Abstract/Summary: The article -which discusses the Report on Human Development in Bolivia 2000- questions what does globalization mean for a country? Is it possible to measure it from the subjective dimensions of social interaction? What are the limits to the alteration of the "social personality" of nations? In order to be projected into the globalized world it is necessary to interact starting from the definition of "self" interests. It is necessary to define the changes in the paradigms of subjectivity to take upon the comparison and examine the aptitudes to preserve and modify the nation. In short, Are we building specific ways to be at the times of globalization? The way to understand ourselves within the "powers" of globalization is to have a minimum arsenal of "knowledge". It is a measure of the autonomy to relate to others. It allows you to "negotiate" the insertion inside globalization, which sets the ways of a joint and conflictive construction of the directions of historicity (commitments). With respect to the remaining tasks, in the political field, the article states that institutions should be strengthened: when society besieges them with its contradictory dynamics, institutions cannot build their valuing logic. In the economic field, should the sense of competitiveness be redirected: Can efficiency be directed towards solidarity? In the social field, extreme poverty must be overcome: there is a huge inability to arrive to a national agreement against poverty, since political agreements do not have supporting social agreements.

Education comes out as the possibility to (re)cognize international insertion as an opportunity. It is a wager for citizenship, an exercise of the ability to elect the users of democracy. The use of the institutions of democracy is supported by the uninterrupted establishment of citizenship. In order for values to become part of development they should be plural and should be acknowledged within the historical sense of each society. The author suggests that the type of association between the rational and the affective should be discovered, as well as getting a definition of individuation, the role that the leading elite classes carry out in these processes is mentioned also.

Key words: Report on Human Development, civil society, globalization effects, Bolivia.

\section{POLITICAL JUDGEMENT OR LEGISLATIVE COUP? ON THE CONSTITUTIONAL CRISES OF THE 1990s ANíbal Pérez Liñán}

Abstract: This paper compares the political crises leading to the demise of the administrations of Fernando Collor in Brazil (1992), Carlos Andrés Pérez in Venezuela (1993), Abdalá Bucaram in Ecuador (1997) and Raul Cubas Grau in Paraguay (1999). Those cases are compared in terms of their similarities, and the administrations of Carlos Menem, Alberto Fujimori and Ernesto Samper are invoked as a source of differences. The evidence suggests that presidents are likely to be impeached whenever three factors act in conjunction: a) political scandal erodes presidential authority; b) public opinion is mobilized against the president -typically as the result of an economy in crisis; and c) the chief executive lacks resources to control congress. Underlying these forces, there is usually a marked isolation of the president and strong elite opposition to his or her style of government.

Keywords: Impeachment, institutional crisis, Executive Branch, Congress, political scandals. 